\title{
Assessment of forest tenure rights of legal recognition, respect, allocation and transfer in Vietnam
}

\author{
Đánh giá các quyền hương dụng rù̀ng về các nội dung ghi nhận, tôn trọng, giao \\ và chuyển nhurợng ở Việt Nam \\ Research article
}

Hoang Lien Son, Le Thi Tuyet Anh*

Forestry Economics Research Centre, Vietnamese Academy of Forest Sciences, Duc Thang ward, Tu Liem North district, Hanoi city, Vietnam

\begin{abstract}
This assessment reviewed 79 legal documents related to forest land tenure that include: 1 Constitution; 8 Laws; 1 Resolution; 20 Decrees; 30 Circulars, 18 Decisions and 1 Directive. The objective of this paper was to assess the forest tenure rights in the system of Vietnam forest tenure policies. The main research method was based on the assessment framework Voluntary Guidelines on the Responsible Governance of Tenure of Land, Forests and Fisheries (VGGT). The results of 2 theme groups (i-Legal recognition and respect of rights; ii-Legal allocation and transfer of tenure rights and duties), corresponding to the seven criteria showed that its marks were at from 1 to 3 (the system of forest tenure policies in Vietnam has attained "slightly addressed" to "mostly addressed" (mark 3 ). However, it has not yet gained the levels of "fully addressed" (mark 4) for all aspects of forest tenure rights.
\end{abstract}

Báo cáo này đã rà soát phần lớn các chính sách hiện hành quan trọng của hưởng dụng rùng với tổng số 79 văn bản, gồm: 1 Hiến pháp; 8 Luạt; 1 Nghị quyết; 20 Nghị định; 30 Thông tu;; 18 Quyết định và 1 Chỉ thị. Mục tiêu của bài viết này là đánh giá các quyền hưởng dụng rùng trong hẹ thống các chính sách hường dụng rùng ở Việt Nam. Phương pháp nghiên cứu chính được dựa trên khung đánh giá của Hương dẫn tụ nguyện về Quản trị chịu trách nhiệm của huởng dụng đất, lâm nghiệp và thủy sản (VGGT). Kết quả nghiên cưu 2 nhóm chủ đề (i-Sụ ghi nhận và tôn trọng các quyền; iiTính pháp lý của việc giao và chuyển nhuợng quyền hương dụng và các nghĩa vu), tương ứng với 7 tiêu chi đều cho thấy mói đạt mức điểm tù̀ 1 - 3 (tức là hệ thống chính sách hường dụng rùng hiện hành ở Việt Nam đã có nhũng nội dung "giải quyết một phần" đến "giải quyết phần lớn" (điểm 3), tuy nhiên chưa có được mức độ "giải quyết đầy đủ” các khía cạn về quyền hương dụng rùng (điểm 4).

Keywords: forest tenure rights, forest tenure policies, forest tenure regulations

\section{Introduction}

In Vietnam, there is 33.12 million hectare (Mha) of the total national inland territory, of which forest covers 13.79 Mha, representing approximately $40 \%$ of the total area of Vietnam (VNFOREST, 2015). Before "Doi Moi" policy (economic reform) initiated in 1986, most forests were under government management and administration. In 1990s, legal framework related to forest tenure changed toward inclusion of multi-stakeholders in the management of forests, such as private sector, communities, and individual households.
According to Law on Forest Protection and Development 2004 (LFPD, 2004) and the Decision No.3135/QD-BNNTCLN dated $06^{\text {th }}$ August 2015, there are eight stakeholders actively engaged in managing forestland and forest areas in Vietnam: State organizations (Forest Management Board for special use forest and protection forests; State Forest Company, army and mass organizations); private sector (other economic organizations, individuals and households); village community; and Commune People's Committee (CPC). In the last 20 years, Vietnam has adopted the process of change in forest policies and institutions by reforming forest tenure. As a result, forest areas 
have been increasingly allocated to private sectors such as individual and households.

Against this backdrop, this report focuses on review of current forest tenure policies to find out the qualitative evidences, policy gaps and suggests practical recommendations to address policy gaps for those related to forest tenure rights.

\section{Methodology}

This article focused on 2 key laws (Land Law, 2013 and LFPD, 2004) and some bylaws related to forest tenure rights of these laws in the total of 79 policy documents of the project. The assessment framework of this article covers 2 thematic areas related to forest tenure rights to review against the qualitative indicators/benchmarks developed for each theme as per guiding and implementation principles of the VGGT. These themes were analyzed with the help of diagnostics questions as sub themes (criteria) to summarize the qualitative assessment with the use of Likert scaling (0-4) and find out the missing elements in the current forest tenure policies. The following themes and criteria were covered by the assessment:

\subsection{Legal recognition and respect of rights}

Recognition of a broad spectrum of existing forest tenure rights and rights holders and their duties by the regulatory frameworks (for both statutory and customary tenure).

Recognition and respect of legitimate tenure right holders and their rights in terms of having elements of bundle of rights: access, use, management, exclusion, and alienation.

System of formal recording of legitimate tenure rights holders and their rights exists.

Tenure rights are well secured considering the security features: duration, scope, clarity, level of restriction on rights, protection of rights from arbitrary withdrawal or breaching.

\subsection{Legal allocation and transfer of tenure rights and duties}

Clear and explicit mechanism devised to allocate and transfer forest tenure rights and duties from the state to other actors.

Right holders received fair compensation and advance information to get consent if the rights are to be eliminated.

Assured security of the transferred rights from the state to the non-state actors.

\section{Results and discussion}

\subsection{Legal recognition and respect of rights}

3.1.1. Recognition of a broad spectrum of existing forest tenure rights and rights holders and their duties by the regulatory frameworks (for both statutory and customary tenure)

Current regulatory framework broadly recognizes and respects forest tenure rights of the legitimate tenure holders and explains about obligations of forest managers and users. Such recognition has been attributed through the following legal instruments. Under Clause 2 Article 54, Vietnam's Constitution, 2013 stated that: "Organizations and individuals are entitled to land allocation and lease, recognition of land use rights. The land users have the rights to transfer and exercise the rights and follow obligations as prescribed by the Law. The land use right is protected by law". Similarly, there are a number of Articles under Land Law (LL, 2013) and LFPD, 2004 which recognize the rights of legitimate tenure holders. For example, Article 2 and 7; Articles 173 to 187 LL, 2013; Articles 59 to 78 LFPD, 2004 have included statement to ensure inclusiveness and expand land use rights of organizations or individuals. These Articles also help creating a broad and diversified network of land managers and users as well as a nation-wide forest owner system with their rights extended depending on specific forest types and forest owners whose tenure rights are being protected that including 11 basic rights: (1) right to harvest products on forest; (2) right on management; (3) right to collect Non timber forest products (NTFPs) in the forest; (4) right to Land Use Right Certificates (LURCs); (5) the duration and scope of the allocated forest area; (6) right to transfer: (7) right to exchange/convert; (8) right to donate: (9) right to mortgage; (10) right to inherit; and (11) right to sell land use rights.

\section{Policy gaps and recommendations}

The recognition and respect of tenure rights are limited only of those covered by statutory legal policies. The traditional rights of customary tenure holders are not articulated in a wide and clear manner. This is one of the notable gaps of the current regulatory framework. Under the current law, the State only allocates forest land to village communities having customary practices with limited rights and no rights to harvest timber and forest products for commercial purposes (Article 30 LFPD, 2004). Therefore, the study recommends amendments of this law in order to strengthen the legal rights of customary communities particularly the rights to harvest timber for commercial use.

\subsubsection{Recognition and respect of legitimate tenure right holders and their rights}

There are a number of arrangements under the current laws and regulation which recognize and respect the rights of legitimate tenure holders. Some of the provision includes: the right on accessibility (In Clause 4 Article 13, Article 20, Points a and b Clause 2 Article 32 LFPD, 2004); right to harvest/use of forest products (Clause 3, 5 Article 59 LFPD, 2004); right to management (Clause 1 Article 37 LFPD, 2004); right to exclusion (Clause 7 Article 166 LL; Clause 8 Article 59 LFPD, 2004); right to transfer (Clause 2 and 3 Article 167, Clause 1 Article 73 LL, 2013),...

\section{Policy gaps and recommendations}

The production forest allocated by the State to the organizations with authority of collection of forest use levies or transfer, there are two cases: (1) in the first case the paid forest use levies originated from the State budget, forest 
owners are allowed to mortgage, provide guarantee or contribute capital with the added value of forest use rights brought about by the forest owners' investment (Clause 1 Article 64 LFPD, 2004); (2) in the second case the paid forest use levies are not originated from the State budget, forest owners are allowed to mortgage, guarantee or contribute capital with the value of the forest use right, value of planted production forest (Clause 2 Article 64 LFPD, 2004). In the situation where production forest is allocated to households and individuals there will also be two scenarios (1) in the case of plantation forest, forest owners are allowed to transfer, donate, lease, mortgage, guarantee or contribute capital with the forest value; and inherit forest land use right (Clause 2 Article 70 LFPD, 2004); (2) in the case of natural production forest, forest owners are only allowed to mortgage, guarantee or contribute capital with the added value of forest use rights brought about by the forest owners' investment and to inherit land use right (Clause 3 and 4 Article 70 LFPD, 2004).

The analysis revealed that - Article 64 of the LFPD, 2004 and the related bylaws have not provided sufficient guidance to enable proper understanding and implementation, particularly the determination of added values for natural production forest. On the other hand, as prescribed in Article 113 LL, 2013; Articles 69, 70 of the LFPD, 2004 and Article 32 Decree No.23/2006/ND-CP, households' use rights on natural forest are narrower than that applied for the land use. The transfer of these two rights must be undertaken simultaneously as they are closely interlinked. Therefore, it is necessary to revise and improve the legal documents with clear methods on determining baseline and added values of forests while ensuring consistent regulations on transfer of forest tenure rights associated with land tenure rights.

\subsubsection{System of formal recording of legitimate tenure rights holders and their rights}

LURC is a legal certificate in which the State certifies the lawful land use rights and ownership of houses and associated properties of the individual who has land use rights and ownership (Clause 16 Article 3 LL, 2013). The following system officially records the tenure rights of land users as prescribed by law:

The official system recognizing the legal land tenure rights are included in Articles 95, 100, 101, 102 LL, 2013; and from Article 5 - 10 Circular No. 23/2014/TT-BTNMT). Additionally, users as forest owners have the right to register forest use rights and ownership over planted production forest (Article 31 LFPD, 2004).

The official system recognizing tenure rights also determines implementation authorities: Provincial People's Committees (PPC) shall grant LURC and ownership of other assets to organizations, investment projects (Clause 1 Article 105 LL, 2013); District People's Committees (DPC) shall grant the LURC and ownership of land-attached assets to households, individuals and communities, and to overseas Vietnamese (Clause 2 Article 105 LL, 2013). The maximum term for tenure rights over the allocated/leased land for forest production is 50 years (Paragraph 1 Clause 3 Article 126 LL and Clause 2 Article 59
LFPD, 2004); In any locations with difficulties, the duration of the tenure rights certificate is 70 years and at the expiry of the term, if the land users still have land use needs, they can apply for further extension (Paragraph 2 Clause 3 Article 126 LL, 2013).

\section{Policy gaps and recommendations}

The assessment has identified policy gap in the current regulatory framework under this sub-theme. In particular, the existing inconsistencies and overlaps have affected the legal tenure rights of land users such as: absence of consistencies on allocation, or lease of natural production forest (Clause 1 Article 135 LL and Clause 1 Article 56 LFPD, 2004); missing a unified regulation on the classification of land, forests, forested land and non-forested land (Articles 135, 136, 137, 165 LL, 2013 and Point b Clause 2 Article 7 Decree 43 and LFPD, 2004); existence of different titles related to special use forests and nature conservation areas as stated in the Biodiversity Law, Fisheries Law and IUCN's classification as resulted in complexity, overlapping, confusion in terms of titles and identification signals... These gaps have hindered land users to undertake the granted certificate on tenure rights by the State. Hence, it is recommended to revise and supplement current laws as below.

Revise and supplement Clause 1 Article135 LL to make consistent with the Clause 1 Article 56 LFPD, 2004;

Segregate the forest land in the LL, 2013 (revise Section 2 Chapter X) into one part equal to agricultural land; area of barren land and denuded hills planned for forestry development shall be included in the forest land area;

It is important to classify and regulate consistent titles for special use forest, nature reserve areas as stated in Biodiversity Law, Fisheries Law and IUCN's classification.

\subsubsection{Security of tenure rights}

The existing legal documents essentially cover most of the tenure security measures as evident from the following provisions under various Laws and Regulation.

The duration of tenure under forest land allocation is maximum for 50-70 years (Paragraph 1 and 3 Clause 3 Article 126 LL, 2013 and Clause 2 Article 59 LFPD, 2004);

As regulated in the existing legal documents, the allocation quota to households and individuals is defined on the basis of region and land-use classification, such as: delta, mountainous region; annual crops; perennials trees and function based land use classification. Depending on different regions, households and individuals are allocated land as classified in addition to the defined land limits. Households and individuals allocated protection and production forests (not more than 30 ha) by the State without land use levies (Clause 3 Article 129 LL, 2013). In case, households/individuals are allocated with multiple land types, then the allocation quota for production forest must not exceed 25 ha (Paragraph 3 Clause 4 Article 129 LL, 2013).

Land tenure rights are guaranteed in each of the specific conditions (Article 188 to 194 LL, 2013). For forest land, 
the allocation/lease of forest, forest recovery and conversion of forest use purpose have to ensure 3 principles of competence while ensuring consistency in terms of time, duration and limits between land and forest (Article 22 LFPD, 2004).

In case of land acquisition by the State, the security of the rights of legitimate tenure holder is guaranteed by the current laws and regulation. If the State recovers the land for national defence, security planning or for the purpose of socio-economic development, the termination of the land tenure rights shall be made in accordance with the regulations specified at Article $61-65$ LL, 2013. Every legitimate land user whose land is recovered is notified, guided, advocated and convinced regarding land acquisition (Article 69, 71 LL, 2013), supported in terms of training, employment and new accommodation (Article 83 to $87 \mathrm{LL}$, 2013; Decree No.47/2014/ND-CP and Circular No. 37/2014/TT-MONRE).

\section{Policy gaps and recommendations}

Various legal provisions have failed to ensure security of land tenure for legitimate land owners. Principles on forest allocation, lease, recovery and conversion of forest use (Article 22 LFPD, 2004) are incomplete and there is lack of transparency, publicity and consensus. As a consequence, there are some cases where land users have not followed the approved forest protection and development plans or regulations on forest land use; local communities are not considered as real forest owners as they do not have all the land tenure rights compared to other forest owners (Article 28 LFPD, 2004). From a practical point of view it would be too large to allocate $25-30$ ha of forest land to each household and individual. However, this area turns to be small in case of natural forest as its harvesting cycle remains $30-35$ years. The following recommendations to address above gap do not directly relate to the revision and amendments of the legal documents related to these issues, but focus on addressing the root causes of these gaps, more specifically.

Revise and develop a sound basis and mechanisms for land valuation; for timely and appropriate compensation. It is crucial to have resettlement policies when recovering people's land, changing employment for local people consistent with the specific conditions in each region and mechanisms for handling cases of infringement.

Improve legal regulations for community forest management, develop proper forest valuation policy, settle disputes and handle all cases of illegal conversion of forest land to other purposes.

\subsection{Legal allocation and transfer of tenure rights and duties}

3.2.1. Mechanism to allocate and transfer tenure rights and duties from the state to other actors

The transfer of forest tenure rights and obligations from the State to other stakeholders are clearly stipulated in many legal documents. We can classify these documents into two categories as follows.
Legal documents regulating and determining the contents related to the ownership and land use rights. In particular, regulating the State in representing the entire-people as owner of land and uniformly managing land, the regime of land management and use, the rights and obligations of land users (Article 1 LL, 2013);

Legal documents specifying the rights and obligations of forest owners allocated/leased forest land by the State ensuring 8 common rights (Article 59 LFPD, 2004) and 6 common obligations (Article 60 LFPD, 2004). In order to materialize these rights and obligations, the State has issued the relevant mechanisms specified for each type of forest owners (Article 59 to 78 LFPD, 2004), as well as to the type of activities (Article 13 - 21 and Article $22-30$ of LFPD, 2004; Circular No. 24/2009/TT-BNN).

\section{Policy gaps and recommendations}

There exists slow administrative reform, particularly in the granting of LURCs, no clear and precise objectives of forest management and use. Very often, policies concerning tenure rights of natural forests tend to prioritize the protection of forest resources owned by the State while "forgetting" or paying little attention on benefits of the owners. The rights to convert, transfer, donate or lease forests or forest use rights, the rights to mortgage, guarantee or contribute capital as the value of rights on natural production or plantation forest utilization are specified for each forest owner associated with different property regime and investment funds. For plantation production forests, which are not funded by the State budget, the above rights and obligations of the forest owners are guaranteed under a clear and specific mechanism. In particular, the transfer of tenure rights on natural production forests based on the added value of forest resources is not feasible because the initial value of the forest capital has not been identified while allocating forests to the users.

Hence, it is recommended to revise and supplement the entire Chapter V: The rights and obligations of forest owners -LFPD, 2004 in order to elaborate about the transfer of rights.

\subsubsection{Compensation and advance information to get consent if the rights are to be eliminated}

One of the important rights of land holders is to receive fair compensation and advance information and get consent if the given rights are to be eliminated. Contents of the current policy mainly LL, 2013 fully addressed this and institutionalized the process. Before issuing a decision on land recovery, the information should be provided at least 90 days prior to the recovery of agricultural land or 180 days prior to the recovery of non-agricultural land. Concern State agencies shall notify the related information to the land users about the land recovery (Clause 1 Article 67 LL, 2013); Notify land users of the land recovery with all the steps for joint collaboration (Article 69; 71 LL, 2013). Land users are entitled to the compensation of their labor fruits, investment results or recovered property. The compensation shall be made in different forms in order to stabilize the land users' livelihood and to provide training to facilitate changing job of the land users (Clause 2 Article 26 LFPD, 2004). 
The State sets land valuation principles, enacts the land price framework, which is adjusted on a 5-year basis (Article 112 to $116 \mathrm{LL}, 2013$; Article 6 to 20 Decree No.44/2014/ND-CP). Land price is determined by the methods of direct comparison, subtraction method, income-based method, surplus-based method, adjustment coefficient based method (Article 2 Decree 44/2014/ND-CP). The price compensation, while recovering land is based on the current land price framework and following the calculation methods. The development or determination of land prices that ensure objectiveness, rights and equal compensation to land users whose land is to be recovered could only be made at the request of competent State agencies (Article 115 LL, 2013).

\section{Policy gaps and recommendations}

The absence of an independent consultant could be seen as the largest gap to ensure fair compensation, advance notification and consensus when land tenure rights are recovered. Consulting activity could only be carried out at the request of the competent State agencies or relevant actors. The second gap refers to the investment on land, especially related to forest. It is not appropriate that forest users are not entitled for the added value generated from the additional investment apart from the State investment in forest (Point b Clause 3 Article 26 LFPD, 2004). In natural forests, forest users could enjoy the added value of forest. However, suitable valuation methods still lack and forest values have not yet been defined when forests are allocated. Therefore, an appropriate valuation method should be developed. Besides, the policy should allow forest users to invest for value addition.

\subsubsection{Assured security of the transferred rights from the state to the non-state actors}

The non-state actors as non- state economic sectors are granted land use rights by the State. In order to ensure security of the tenure rights transferred from the State to nonstate actors, all the non-state actors are legally defined (Article 5 LFPD, 2004) and their tenure security is assured through existing regulations. The State protects and facilitates the legal transfer of land use rights as per Article 52 to 60 LL, 2013; Clause 8 Article 59 LFPD, 2004; and Article 66; 114 LL, 2013.

\section{Policy gaps and recommendations}

In this process, provincial people committee is holding much authorities in terms of land allocation and issuance of permission on conversion of land use purposes as stipulated in Clause 1 Article 59 LL, 2013; Clause 1, Article 66 LL, 2013; and land valuation Article 114 LL, 2013. Hence, there are following recommendations:

Supplement M\&E element by including provision of an independent consultation mechanism in the current legislation so as to ensure security for the tenure rights transferred from the State to non-state actors within the mandates of PPC.
Revise and supplement issue on security assurance during the process of transferring tenure rights from the State to non-state actors, particularly on LFPD, 2004.

\subsection{The total results}

The assessment results were drawn based on the Likert scale ranked with specific score for each sub theme and aggregated value of each criterion was divided by the number of sub themes to calculate the score for each theme. The result of such scoring is as follows.

Table 1: Mark for the criteria of forest tenure rights

No Themes/Criteria $\begin{gathered}\text { Current } \\ \text { marked } \\ 0-4^{*}\end{gathered}$

a Legal recognition and respect of rights

Recognition of a broad spectrum of existing forest tenure rights and rights

i holders and their duties by the regulatory frameworks (for both statutory and customary tenure)

Recognition and respect of legitimate tenure right holders and their rights in

ii terms of having elements of bundle of rights: access, use management, exclusion, and alienation System of formal recording of legiti-

iii mate tenure rights holders and their rights exists

Tenure rights are well secured considering the security features: duration,

iv scope, clarity, level of restriction on rights, protection of rights from arbitrary withdrawal or breaching

b Legal allocation and transfer of tenure rights and duties

Clear and explicit mechanism devised to allocate and transfer forest tenure rights and duties from the state to other actors

Right holders received fair compensaii tion and advance information to get consent if the rights are to be eliminated

Assured security of the transferred

iii rights from the state to the non-state actors

The table above shows that none of the themes are fully addressed by the current regulatory framework on forestland tenure rights in Vietnam. All criteria of theme 1 scored 3 illustrate that current policies are moderately addressed the issues in terms of recognition of rights of legitimate tenure holders. Likewise, the criterion b-iii of theme 2 marked 1 - the slightly addressed level, that perform that

* Extent of addressing principles of VGGT: 0- not addressed at all;1- slightly addressed, 2-moderately addressed, 3- mostly addressed, 4- fully addressed 
there is an urgent need to revise or promulgate some new policies and regulations in favour of theme number 2 .

\section{Conclusions}

This assessment reviews 2 key laws (LL, 2013 and LFPD, 2004) and the bylaws related to forest tenure rights of these laws. Most of the bylaws were promulgated to create a complete legal framework. The LFPD, 2004 has created a quite comprehensive legal basis for forestry activities although its title only refers to forest protection and development. Most of the elements of bundle of rights such as: access, use, management, exclusion, and alienation are recognized by the current regulatory framework; clear and explicit mechanism devised to allocate and transfer forest tenure rights and duties from the state to legitimate forest owners and have 8 rights secured with 6 common obligations...

Despite having certain strengths of existing regulatory framework in Vietnam there exists a number of shortcomings and limitation which inhibit the process of securing forest land tenure and realizing the potential benefits, such as:

There are inconsistencies between the LFPD, 2004 and the LL, 2013 and such inconsistencies exist in a number of respective by laws such as: Decree 43, Decree 23, Decree 48; Circular 65, Circular 38.

Chapter V: Rights \& obligations of forest owners under the LFPD, 2004 does not provide full tenure rights for securing forest tenure.

The LFPD, 2004 is rather generic and follow the basis with a lot of announcements and listing of contents rather than stipulating regulations for implementation.

There exist lacks of clarity in LFPD, 2004 regarding rights and obligations of forest owners. Therefore, it fails to encourage forest owners as state forest entities to take initiatives and ensure autonomy in production and business.
The formal forest /forestland tenure granted by the State to the village communities is rather limited. Meanwhile, the informal tenure rights (customary laws) have not been recognized by the existing legal system.

\section{References}

[1] Bebbington, Anthony (1999):"Capitals and capabilities: A framework for analyzing peasant viability, rural livelihoods, and poverty". World Development, 27(12), 2012-2044.

[2] Bradstock, Alanstair (2005): "Changing livelihoods and land reform: Evidence from the Northern Cape Province of South Africa". World Development, 33(11), 1979-1992.

[3] Cahn, Miranda (2002): "Sustainable livelihoods approach: Concept and practice". Paper presented to Dev Net 2002 Conference on Contesting Development: Pathways to Better Practice, The Institute of Development Studies at Massey University, 5-7 December, New Zealand.

[4] Dahal GR (2015): "Forest land tenure policy and legal assessment - Vietnam". A presentation at the first national policy dialogue on Strengthening Forest Tenure for Sustaining Livelihood and Generating Income.

[5] FAO (2012): "Voluntary Guidelines on the Responsible Governance of Tenure of Land, Fisheries and Forests in the Context of National Food Security". FAO Rome.

[6] Hoang Lien Son, Le Thi Tuyet Anh (2016): "Forest Tenure Policy Assessment in Vietnam". The last research report of the project "Strengthening Forest Tenure for Sustaining Livelihood and Generating Income". Hanoi, July 2016. 